\title{
Formula-Based Approach in the Allocation of Specific Allocation Grants for Infrastructure (DAK Fisik): Case of Education Provision
}

Tengku Munawar Chalil ${ }^{*}$ and Mohammad Roudo ${ }^{2}$

${ }^{1}$ School of Architecture, Planning and Policy Development Institut Teknologi Bandung and ${ }^{2}$ Ministry of National Development Planning (Bappenas)

*Corresponding author. Email: tengkumunawarchalil@gmail.com

Submitted: July $26^{\text {th }} 2020$ | Accepted: September $21^{\text {st }} 2020$ | Published: September $28^{\text {th }} 2020$

\begin{abstract}
The paper presents the top-down (formula-based) approach in the allocation of specific purpose grants for infrastructure (DAK Fisik) in education by considering the specific needs related to the infrastructure in education. First, we estimate the needs of education infrastructure by calculating the gap between the current condition of infrastructures and the minimum required infrastructures in education. Then, we translate the needs into necessary costs for education per region. After that, we simulate financial scenarios for the necessary costs using specific allocation grants in hierarchical, temporal, and regional dimensions. We also consider the local fiscal capacity and indicators for the achievement of local governments in education for the distribution of DAK Fisik for FY2021 and onward. Finally, we provide the potential implications of using the formula-based approach as a topdown planning and budgeting tool for DAK Fisik.
\end{abstract}

Keywords: Infrastructure Costing, Specific Allocation Grants, Education 


\title{
Formula Based Approach in the Allocation of Specific Allocation Grants for Infrastructure (DAK Fisik): Case of Education Provision
}

\author{
Tengku Munawar Chalil and Mohammad Roudo
}

\section{Introduction}

The increase of the allocation and scope of Specific Allocation Funds for infrastructure (DAK Fisik) in fact still procures many flaws and problems, both at the central level and the local level. Some problems, for instance, are the mismatching between the expenditure menu and the needs of the local government, a late announcement of technical guidance, postponed implementation by a third party, which can cause fewer outputs and outcomes regarding DAK Fisik. Therefore, the ministry of national development planning (BAPPENAS) has accomplished various efforts to further enhance the quality and governance of DAK Fisik, including process, cycle, and management mechanisms through a proposal-based approach.

Since 2016, the allocation of DAK Fisik is not determined by the central government by general, specific and technical criteria. ${ }^{1}$ The allocation of DAK Fisik has to conform with the national priority and fiscal capacity, and the most important consideration is the proposals submitted by the local government. The President's direction addresses the allocation of DAK Fisik with a preference to use the bottom-up approach instead of the topdown approach. This means that the central government must take into high consideration the proposals from local governments to accommodate their specific needs. In 2016, the local governments still forwarded each individual proposal manually to the central government, however, since 2017, BAPPENAS has initiated the utilization of e-planning so DAK Fisik proposals are submitted through the utilization of the e-planning application process instead of them being manually submitted. Then this application transforms towards the utilization KRISNA application, which is one gate portal to submit DAK Fisik proposals from local government. This system is later connected with other systems such as OM-SPAN, a financial system to disburse money to the successful applicants. All related stakeholders can access this application, from the submission of proposals, verification of proposals and data, as well as synchronization, between planning and budgeting.

Even though current planning of specific allocation funds are based on each proposal, the Ministry of National Development Planning initiates the partial use of a fixed formulabased approach on the allocation of DAK Fisik for FY2021. Learning from past experience, previous planning of DAK Fisik is dominantly driven by each specific proposal from the local government. Therefore, it is important to use a formula that can accommodate big data, fiscal capacity, statistics, and other technical data which are related to sectoral data, construction index and spending disbursement in the previous fiscal year. We expect that the use of this formula could represent the needs of local government in an equal and impartial manner. In

\footnotetext{
${ }_{1}^{1}$ Technical criteria are naturally a top-down process. A ministry/agency decides the technical criteria for a specific allocation of funds. Law 33/2004, Article 40 mentions this matter specifically.
} 
the future, the evolution on the concept of DAK Fisik will be set as a combination between proposal-based and formula-based approaches.

Thus, this paper introduces the formula-based approach for the allocation of $D A K$ Fisik, particularly in the case of the fulfillment of the education infrastructure. Some steps need to be taken when following this formula-based approach. First, developing a formula to estimate the needs of the education infrastructure per region using the current infrastructure data. Second, setting the goal for the education infrastructure to calculate the gap between the current condition and the needs sought after. Third, measuring the cost of the infrastructure gaps. The funding scenario is also introduced that reflect the gaps in cost. Finally, the funding scenario per region is developed by considering local achievement and fiscal capacity.

Our paper contributes both to the academic field and policy recommendation. First, this paper enriches the literature on public finance particularly on the corpus of fiscal needs and allocation. This is in line with the idea presented by Procelli and Vidoli (2019) who constructed expenditures' needs from a supply and demand curve and also from citizens' income. Shah, Qibtidayah, and Dita (2012) argued that fiscal needs come from an index of area, population, construction price index, human development index, and regional GDP. Mochida (2007) presented the calculation of expenditure needs in Japan, which utilizes the infrastructure gap and unit cost. Our paper estimates the fiscal needs of infrastructure based on the gap of infrastructure which is later transformed into the necessary cost.

Secondly, the paper contributes to giving a breakthrough about the planning and budgeting of DAK Fisik. This paper comes with the idea of balancing a bottom-up approach and a top-down approach regarding the planning process of DAK Fisik. The current process highly explores the bottom-up approach, but less exploration is given to the top-down approach. Our aim is to fill the gap between these different approaches by developing a formula and simulation using a combination of the top-down and bottom-up approaches that can be utilized by the central government as a guideline when discussing grant proposals with local government.

The rest of this paper is constructed by the following: Section 2 reviews the cogent related literature. Section 3 presents the calculation of the infrastructure needs. Section 4 discusses the allocation scenario of specific allocation funds. Finally, Section 5 concludes the paper.

\section{Literature review}

In the literature, the needs of expenditure require financial sources to provide a standard set of public service (Duncan \& Smith, 1996). The standard set of public service is not similar to that with a minimum level service. A standard set of public service can be different across regions, but a minimum level service is fixed by law (Porcelli \& Vidoli, 2019). Expenditure needs can be estimated by a normative approach. Mochida (2007) showed that in the case of Japan, expenditure needs are calculated as the number of measurement units by multiplying the unit cost, adjusted by the modification coefficient. For instance, expenditure needs for road improvement is 380,000-yen x road length $(\mathrm{km}) \mathrm{x}$ modification coefficients. The financing of the expenditure is using Local Allocation Tax (LAT) transfers 
and other legal revenue within local government. The costing practice is similar with the system developed in Australia for calculating special expenditure needs (see, Ma, 1999 for the specific details). Before the calculation of standard expenditure needs, public service for each subnational government is divided into particular service items by function. After that, expenditure needs are calculated using the measurement of necessary unit(s) multiplied by unit $\operatorname{cost}(\mathrm{s})$ and adjustment coefficients.

Focusing on infrastructure needs, Bhattacharyay (2010) noted two approaches for estimating infrastructure demand. The first is the top-down approach. The top-down approach relies on an econometric model, where the demand of infrastructure as the function of per capita income, population density, share of agriculture and manufacture to value added, and the degree of urbanization are taken into account. The top-down approach uses historic trends to forecast the demand. In contrast, the bottom-up approach requires an individual infrastructure project(s) manager to estimate the costs of their implementation. The total of infrastructure costs from all infrastructure projects become the total needs of infrastructure. The issue may arise as a result of the bottom-up process, the planning of infrastructure is less coordinated and inefficient. Moreover, Shick (1998) noted the idea about operational efficiency, which is the best selection of approach based on the efficiency of utilizing money or resources to achieve the desired goals.

The strands of literature also discuss the education needs and government expenditures. West et al. (2001) used the Standard Spending Assessment (SSA) in the United Kingdom to examine the needs of education and its impact. The SSA is the minimum funds for education which the allocation of funds is determined by several of the authorities in different parts of the country and its population characteristics. Stiglitz (1974) noted that the provision of education is an interesting case on the one hand but it also has complex issues attached to it on the other hand, since education in some parts are public goods and other parts are publicly provided private goods. Hirsch (1960) argued that in an ideal setting, the needs of education expenditures are determined by population density, sociology, cultural, and the willingness-to-pay for education. Ladd (1965) found that the property tax has an effect on local government spending on education. Later he argued that this education expenditure relies on local fiscal capacity. Kurban, Gallagher, and Persky (2015) showed that the dynamic of population-cohort affects the needs and priorities of education. Denzau (1975) has surveyed the large volume of literature and suggested that fiscal grants often have a significant positive contribution to education expenditure albeit it does not directly address the needs of education. Apparently, fiscal grants appear as an important source to finance education in developing countries. Other factors such as population density, number of pupils, and family income also magnify the public expenditures for education (Patrinos \& Ariasingnam, 1997).

However, the literature about costing and estimation on the needs of the education sector in Indonesia is limited, as far as the author's knowledge. Therefore, this paper offers the costing of the demand of the education sector in Indonesia and how transfer grants from the central to subnational government, particularly, DAK Fisik, could finance the cost for the needs of the education sector based on its demand. 


\section{Costing the needs of the education infrastructure}

The costing of the needs to fulfil the education infrastructure that is financed by $D A K$ Fisik departs from identifying the current condition of education's infrastructure. In this paper, this education's infrastructure is only limited in scope to the physical infrastructure of education, for example, the amount and condition of the classroom, school library, laboratory, teacher room, closet/toilet, medical room, science and computer laboratory, and other physical infrastructure for education. The capacity of each teacher, teacher and school staff salary, and curriculum are categorized as non-physical infrastructure. Patrinos and Ariasingnam (1977) noted that the local government should finance the expenditures to enhance the capacity of local education using the local budget instead of relying on central government grants. It is important to note that DAK Fisik is addressed to fund the physical infrastructure, while the non-physical infrastructure is financed by DAK Non Fisik.

We utilized the database for principal education (Data Pokok Pendidikan/DAPODIK) year 2020 to illustrate the current condition of the infrastructure within the education sector. We identify the number of the current infrastructure in each tier of the government in each region (district, city, and province). For instance, we calculate the number of science laboratories in elementary school in municipal X. We also probe the number of potential damages of infrastructures in each tier of government and in each region. After the current condition is clearly identified and calculated, then we determine the ideal condition as the goals. The ideal condition of the infrastructure in education follows the target that is stipulated in the Government Regulation (GR) 19/2005 juncto GR 32/2013 on the National Education Standard. We also follow the target of the Ministry of Education and Culture about the target of infrastructure in education which must be financed by DAK Fisik.

The comparison of ideal and current conditions yields the needs of infrastructures within the education sector. The needs of infrastructures consist of two categories: new infrastructure and repairing damaged infrastructures. The total of both infrastructures is then multiplied with the unit cost and construction index, which yield the total cost of the need of infrastructure in education.

$$
\text { Cost of Education Inf. }{ }_{(j k)}=\left(\sum_{i=1}^{n} N e w \operatorname{Inf}_{\cdot i j k}+\sum_{i=1}^{n} \text { Reh. Inf }_{\cdot i j k}\right) x U C \times \frac{C I_{k}}{100}
$$

Where cost of education infrastructure in $j$-level (kindergarten, elementary, junior high, senior high, etc.) and $k$-municipal equal to the total need of new $i$-infrastructure (classroom, library, laboratory, etc.) and repairing of damaged $i$-infrastructure, which is multiplied by Unit Cost (UC) and Construction Index (CI).

The calculation on the needs of infrastructure in education assumes that the ideal condition is all damaged in infrastructures that are repaired and the newly built infrastructures are addressed to all in terms of less quality of infrastructure as stated by the Minister of Education and Cultural, all students must receive a convenient and educational environment that is conducive to study in.

The calculation of infrastructure has three steps. First, we list the infrastructure that must be provided in each tier of government. These needs are different. For instance, a science laboratory is only addressed for elementary and junior high school, while senior high schools require physics, chemistry, biology, and language laboratories. In this paper, the list 
and calculation is made for six levels of education: kindergarten (PAUD), elementary (SD), junior high (SMP), senior high (SMA), vocational school (SMK) and special education school (SLB). We exclude the calculation in senior vocation and university level (undergraduate and graduate levels) since they belong to the central government's authority and out of the scope of this paper. We also accommodate the characteristics of the region as a priority that gains full intervention while other regions only gain partial intervention. Meaning there is an imbalance of interventions across the regions.

First step, we estimate that 504,467 newly built infrastructures, including new classrooms, new laboratories, and other new infrastructures, need to be built across Indonesia. A total of $69.7 \%$ is located in the western part of Indonesia while $30.27 \%$ is located in the eastern part of Indonesia. Furthermore, we estimate 294,828 damaged infrastructures need to be replenished. A total of $67.9 \%$ of this infrastructure is located in the western part of Indonesia while $32.1 \%$ is located in the eastern part of Indonesia.

The second step, multiplying the need to repair the damaged infrastructures using unit cost of each infrastructure. The unit cost of infrastructure is based on the unit cost launched by the Ministry of Education and Cultural in the year 2020. Finally, the result in the second step or total cost of infrastructure is adjusted (multiplied with) the value of the official construction index. We utilize the construction index in the year 2019 launched by the National Statistics Agency (BPS). We estimate approximately 188,57 trillion rupiah is required to fill the needs to revitalize the infrastructure (including construction and restoration) of the education sector, of this, 124,93 trillion rupiah is allocated to the western part of Indonesia while 63,64 trillion rupiah is allocated to the eastern part of Indonesia. Hereby, West Java province receives the highest share (14.4\%), while North Kalimantan receives the lowest share $(0.4 \%)$. Table 1 presents the detailed needs to revitalize the infrastructure and the necessary cost to fund it.

Table 1. The Needs of DAK Fisik FY 2021 -2024 per province

\begin{tabular}{|c|c|c|c|c|c|c|}
\hline No & Province Name & Construction & Rehabilitation & $\begin{array}{l}\text { Cost } \\
\text { (Million } \\
\text { Rupiah) }\end{array}$ & $\begin{array}{l}\text { Needs of } \\
\text { DAK } 2021- \\
2024 \\
\text { (Million } \\
\text { Rupiah) }\end{array}$ & $\%$ \\
\hline 1 & Aceh & 11,466 & 8,843 & $4,668,643.18$ & $4,383,799.80$ & 2.41 \\
\hline 2 & Sumatera Utara & 33,854 & 17,649 & $12,822,594.21$ & $\begin{array}{l}12,495,129.5 \\
6\end{array}$ & 6.88 \\
\hline 3 & Sumatera Barat & 11,357 & 7,490 & $3,754,302.86$ & $3,596,909.18$ & 1.98 \\
\hline 4 & Riau & 13,126 & 7,384 & $4,685,159.94$ & $4,441,335.39$ & 2.44 \\
\hline 5 & Jambi & 7,177 & 5,678 & $2,742,617.20$ & $2,577,580.82$ & 1.42 \\
\hline 6 & Sumatera Selatan & 15,902 & 11,922 & $5,665,926.81$ & $5,490,163.24$ & 3.02 \\
\hline 7 & Bengkulu & 3,841 & 3,566 & $1,544,271.77$ & $1,434,874.19$ & 0.79 \\
\hline 8 & Lampung & 16,670 & 12,381 & $5,610,161.36$ & $5,359,682.30$ & 2.95 \\
\hline 9 & $\begin{array}{l}\text { Kepulauan } \\
\text { Bangka Belitung }\end{array}$ & 2,176 & 2,057 & $916,212.58$ & $857,785.94$ & 0.47 \\
\hline
\end{tabular}




\begin{tabular}{|c|c|c|c|c|c|c|}
\hline \multirow{2}{*}{$\begin{array}{l}\text { No } \\
\cdot \\
\\
10 \\
\end{array}$} & \multirow{2}{*}{$\begin{array}{l}\text { Province Name } \\
\\
\text { Kepulauan Riau }\end{array}$} & \multicolumn{2}{|c|}{$\begin{array}{l}\text { Needs of Infrastructure (unit) } \\
\text { Construction Rehabilitation }\end{array}$} & \multirow{2}{*}{$\begin{array}{l}\text { Cost } \\
\text { (Million } \\
\text { Rupiah) } \\
\\
1,802,643.06\end{array}$} & \multirow{2}{*}{$\begin{array}{l}\text { Needs of } \\
\text { DAK 202 1- } \\
\text { 2024 } \\
\text { (Million } \\
\text { Rupiah) } \\
\\
1,664,972.39\end{array}$} & \multirow{2}{*}{$\begin{array}{l}\% \\
\\
\\
0.92 \\
\end{array}$} \\
\hline & & 3,829 & 1,678 & & & \\
\hline 11 & DKI Jakarta & 7,517 & 4,636 & $3,393,285.26$ & $3,393,285.26$ & 1.87 \\
\hline 12 & Jawa Barat & 89,427 & 35,889 & $27,158,688.91$ & $\begin{array}{l}26,368,834.5 \\
9\end{array}$ & $\begin{array}{l}14.5 \\
2\end{array}$ \\
\hline 13 & Jawa Tengah & 45,466 & 31,489 & $16,903,548.60$ & $\begin{array}{l}16,646,268.6 \\
8\end{array}$ & 9.16 \\
\hline 14 & DI Yogyakarta & 3,615 & 3,331 & $1,539,613.08$ & $1,430,253.81$ & 0.79 \\
\hline 15 & Jawa Timur & 58,069 & 35,308 & $22,632,203.54$ & $\begin{array}{l}22,162,064.6 \\
3\end{array}$ & $\begin{array}{l}12.2 \\
0\end{array}$ \\
\hline 16 & Banten & 21,745 & 8,292 & $6,486,206.09$ & $6,400,903.21$ & 3.52 \\
\hline 17 & Bali & 7,314 & 2,741 & $2,607,972.81$ & $2,550,942.24$ & 1.40 \\
\hline 18 & $\begin{array}{l}\text { Nusa Tenggara } \\
\text { Barat }\end{array}$ & 12,978 & 6,811 & $4,902,657.87$ & $4,761,645.80$ & 2.62 \\
\hline 19 & $\begin{array}{l}\text { Nusa Tenggara } \\
\text { Timur }\end{array}$ & 17,751 & 14,228 & $7,590,729.86$ & $7,244,960.08$ & 3.99 \\
\hline 20 & Kalimantan Barat & 13,820 & 11,098 & $6,472,555.22$ & $6,264,783.04$ & 3.45 \\
\hline 21 & $\begin{array}{l}\text { Kalimantan } \\
\text { Tengah }\end{array}$ & 8,791 & 4,504 & $3,310,273.00$ & $3,065,692.74$ & 1.69 \\
\hline 22 & $\begin{array}{l}\text { Kalimantan } \\
\text { Selatan }\end{array}$ & 7,665 & 4,509 & $2,809,251.52$ & $2,717,584.71$ & 1.50 \\
\hline 23 & $\begin{array}{l}\text { Kalimantan } \\
\text { Timur }\end{array}$ & 7,226 & 3,088 & $2,695,689.94$ & $2,490,542.50$ & 1.37 \\
\hline 24 & Kalimantan Utara & 1,710 & 1,019 & $747,850.00$ & $656,245.28$ & 0.36 \\
\hline 25 & Sulawesi Utara & 7,089 & 4,208 & $2,866,675.70$ & $2,653,489.98$ & 1.46 \\
\hline 26 & Sulawesi Tengah & 10,039 & 6,203 & $3,491,581.70$ & $3,241,690.88$ & 1.78 \\
\hline 27 & Sulawesi Selatan & 20,537 & 15,362 & $7,285,649.38$ & $7,077,710.25$ & 3.90 \\
\hline 28 & $\begin{array}{l}\text { Sulawesi } \\
\text { Tenggara }\end{array}$ & 8,568 & 6,138 & $3,364,862.50$ & $3,134,505.49$ & 1.73 \\
\hline 29 & Gorontalo & 2,583 & 1,671 & $991,590.57$ & $931,815.92$ & 0.51 \\
\hline 30 & Sulawesi Barat & 5,180 & 4,013 & $1,904,850.68$ & $1,697,997.02$ & 0.93 \\
\hline 31 & Maluku & 7,042 & 4,097 & $3,271,285.77$ & $3,050,595.66$ & 1.68 \\
\hline 32 & Maluku Utara & 6,483 & 2,722 & $2,766,495.68$ & $2,569,853.17$ & 1.41 \\
\hline 33 & Papua Barat & 4,155 & 1,549 & $1,782,697.23$ & $1,616,535.50$ & 0.89 \\
\hline 34 & Papua & 11,462 & 3,294 & $7,384,655.15$ & $7,225,940.84$ & 3.98 \\
\hline & Total & 505,647 & 294,848 & $188,573,403$ & $181,656,374$ & 100 \\
\hline
\end{tabular}




\begin{tabular}{|c|c|c|c|c|c|c|}
\hline \multirow{6}{*}{$\begin{array}{l}\text { No } \\
\text {. }\end{array}$} & \multirow[t]{2}{*}{ Province Name } & \multicolumn{2}{|c|}{ Needs of Infrastructure (unit) } & \multirow{2}{*}{$\begin{array}{l}\text { Cost } \\
\text { (Million } \\
\text { Rupiah) }\end{array}$} & \multirow{2}{*}{$\begin{array}{l}\text { Needs of } \\
\text { DAK } 2021- \\
2024 \\
\text { (Million } \\
\text { Rupiah) }\end{array}$} & \multirow[t]{2}{*}{$\%$} \\
\hline & & Construction & Rehabilitation & & & \\
\hline & \multirow[t]{2}{*}{ West Indonesia } & $352,559.69$ & $200,334.00$ & $12124,934,051$ & $12121,254,785$ & "66.7 \\
\hline & & & & & & 5 \\
\hline & \multirow[t]{2}{*}{ East Indonesia } & $153,087.59$ & $94,514.00$ & $63,639,351$ & $60,401,588$ & 33.2 \\
\hline & & & & & & 5 \\
\hline
\end{tabular}

\section{Costing the needs of DAK Fisik Pendidikan}

During serial consultations with BAPPENAS and the Ministry of Education and Culture, ${ }^{2}$ it was agreed that DAK Fisik will be funded $100 \%$ for the need of the infrastructure in the education sector. Therefore, towards FY2021 to FY2024 (end of midterm national development plan 2020-2024), it has set the target that 100\% of the education infrastructure will be revitalized in FY2024. In other words, since FY2020, it is stated in the midterm plan document (RPJMN), the need of DAK Fisik in education FY2021-FY2024 is obtained by subtracting the need of the education infrastructure with DAK Fisik in education for FY2020.

Need of DAK $2021-2024_{(j k)}=$ Cost of Education Inf. ${ }_{(j k)}-$ DAK $2020_{(j k)}$

Based on that formula, it is estimated and calculated that the need of DAK Fisik in education FY2021-2024 is approximately 181,66 trillion rupiah which is allocated to the western part of Indonesia to the proportion of about $67 \%$ and about $33 \%$ in the eastern part of Indonesia. The biggest portion of DAK Fisik in education is for elementary schools (54\%), then is followed by junior high schools (17\%), vocational schools (13\%), senior high schools $(10 \%)$, kindergartens $(6 \%)$ and special education schools (1\%). Madrasa is not included in the calculation and analysis since it does not belong to the authority of the Ministry of Education and Culture. The exercise does not also include the need of the cultural academy (SKB) due to lack of data. Table 1 presents per province allocation of DAK Fisik in education FY20212024. Then, we split the funds of DAK Fisik in each fiscal year in the following scenario. In FY2021, the funding is only set for $15 \%$ of completion, amid the economic contraction in FY2020. In FY2022, it is set more optimistically with 35\% of completion. As the economic recovery is projected to get incrementally better, the target accelerates in FY2023, when it is set for $70 \%$ of completion. Finally, the $100 \%$ completion will be achieved in FY2024.

Referring to that percentage, we estimate that the need of DAK Fisik in education in FY2021 is approximately 27,25 trillion rupiah. The total amount that is addressed to the western part of Indonesia is about 18,18 trillion rupiah while the eastern part of Indonesia will receive 9,06 trillion rupiah. We call this scenario a baseline scenario. This scenario assumes all cities and districts receive $100 \%$ of DAK Fisik to finance its needs. Table 2 below presents the details of the per province allocation according to the baseline scenario.

2 The serial consultations for estimating the needs of specific allocation funds for infrastructure FY202 1 and forward were initiated by the Directorate of Regional Autonomy, BAPPENAS with support from KOMPAK. The serial consultations started since March 2020 onwards. 
Table 2. Specific Allocation Funds for Education Infrastructure FY2021 by education level per province (Baseline Scenario) (In Million Rupiah)

\begin{tabular}{|c|c|c|c|c|c|c|c|c|}
\hline No & $\begin{array}{c}\text { Province } \\
\text { Name }\end{array}$ & PAUD & SD & SMP & SMA & SMK & SLB & TOTAL \\
\hline 1 & Aceh & $28,393.7$ & $336,652.5$ & $\begin{array}{l}150,683 . \\
6\end{array}$ & $\begin{array}{l}103,906 . \\
2\end{array}$ & $34,900.7$ & $3,033.3$ & $657,570.0$ \\
\hline 2 & $\begin{array}{l}\text { Sumatera } \\
\text { Utara }\end{array}$ & $60,268.3$ & $\begin{array}{l}1,019,964 . \\
1\end{array}$ & $\begin{array}{l}310,026 . \\
4\end{array}$ & $\begin{array}{l}230,220 . \\
3\end{array}$ & $\begin{array}{l}249,320 . \\
1\end{array}$ & $4,470.3$ & $\begin{array}{l}1,874,269 . \\
4\end{array}$ \\
\hline 3 & $\begin{array}{l}\text { Sumatera } \\
\text { Barat }\end{array}$ & $10,581.0$ & $367,617.5$ & $64,530.8$ & $55,596.6$ & $35,003.0$ & $6,207.4$ & $539,536.4$ \\
\hline 4 & Riau & $20,641.5$ & $361,030.9$ & $\begin{array}{l}143,746 . \\
2\end{array}$ & $82,024.0$ & $57,378.2$ & $1,379.6$ & $666,200.3$ \\
\hline 5 & Jambi & $9,422.9$ & $233,215.1$ & $74,823.5$ & $41,150.0$ & $28,025.7$ & - & $386,637.1$ \\
\hline 6 & $\begin{array}{l}\text { Sumatera } \\
\text { Selatan }\end{array}$ & $41,150.5$ & $429,473.3$ & $\begin{array}{l}180,802 . \\
6\end{array}$ & $\begin{array}{l}112,918 . \\
1\end{array}$ & $57,396.9$ & $1,783.0$ & $823,524.5$ \\
\hline 7 & Bengkulu & 1,838.6 & 130,084.0 & $44,512.9$ & $20,682.2$ & $17,903.2$ & 210.2 & $215,231.1$ \\
\hline 8 & Lampung & $61,706.4$ & $420,552.3$ & $\begin{array}{l}137,308 . \\
8\end{array}$ & $86,159.2$ & $96,482.1$ & $1,743.6$ & $803,952.3$ \\
\hline 9 & $\begin{array}{l}\text { Kepulauan } \\
\text { Bangka } \\
\text { Belitung }\end{array}$ & $15,354.3$ & $73,327.0$ & $18,623.4$ & $10,777.8$ & $10,585.3$ & - & $128,667.9$ \\
\hline 10 & $\begin{array}{l}\text { Kepulauan } \\
\text { Riau }\end{array}$ & $7,047.2$ & $128,387.2$ & $54,638.3$ & $32,045.8$ & $26,655.6$ & 971.9 & $249,745.9$ \\
\hline 11 & $\begin{array}{l}\text { DKI } \\
\text { Jakarta }\end{array}$ & $55,854.7$ & $151,659.9$ & $36,624.2$ & $87,249.4$ & $\begin{array}{l}174,256 . \\
3\end{array}$ & $3,348.2$ & $508,992.8$ \\
\hline 12 & Jawa Barat & $\begin{array}{l}244,445 . \\
9\end{array}$ & $\begin{array}{l}1,950,245 . \\
4\end{array}$ & $\begin{array}{l}650,661 . \\
2\end{array}$ & $\begin{array}{l}298,184 . \\
7\end{array}$ & $\begin{array}{l}795,524 . \\
8\end{array}$ & $16,263.1$ & $\begin{array}{l}3,955,325 . \\
2\end{array}$ \\
\hline 13 & $\begin{array}{l}\text { Jawa } \\
\text { Tengah }\end{array}$ & $\begin{array}{l}225,077 . \\
4\end{array}$ & $\begin{array}{l}1,555,240 . \\
1\end{array}$ & $\begin{array}{l}169,855 . \\
9\end{array}$ & $\begin{array}{l}139,101 . \\
5\end{array}$ & $\begin{array}{l}400,939 . \\
8\end{array}$ & $6,725.6$ & $\begin{array}{l}2,496,940 . \\
3\end{array}$ \\
\hline 14 & $\begin{array}{l}\text { DI } \\
\text { Yogyakart } \\
\text { a }\end{array}$ & $16,375.6$ & $113,755.0$ & $10,225.2$ & $22,824.7$ & $49,222.5$ & $2,135.0$ & $214,538.1$ \\
\hline 15 & $\begin{array}{l}\text { Jawa } \\
\text { Timur }\end{array}$ & $\begin{array}{l}276,571 . \\
9\end{array}$ & $\begin{array}{l}1,683,744 . \\
9\end{array}$ & $\begin{array}{l}455,366 . \\
8\end{array}$ & $\begin{array}{l}309,058 . \\
7\end{array}$ & $\begin{array}{l}578,792 . \\
4\end{array}$ & 20,774 & $\begin{array}{l}3,324,309 \\
7\end{array}$ \\
\hline 16 & Banten & $63,715.6$ & $414,121.0$ & $\begin{array}{l}166,081 . \\
0\end{array}$ & $\begin{array}{l}120,443 . \\
6\end{array}$ & $\begin{array}{l}191,146 . \\
\text { o }\end{array}$ & $4,628.4$ & $960,135.5$ \\
\hline 17 & Bali & $37,104.0$ & $231,384.2$ & $30,547.7$ & $35,681.5$ & $47,852.5$ & 71.4 & $382,641.3$ \\
\hline 18 & $\begin{array}{l}\text { Nusa } \\
\text { Tenggara } \\
\text { Barat }\end{array}$ & $92,451.7$ & $330,546.7$ & $\begin{array}{l}135,470 . \\
6\end{array}$ & $73,640.0$ & $78,984.3$ & $3,153.6$ & $714,246.9$ \\
\hline 19 & $\begin{array}{l}\text { Nusa } \\
\text { Tenggara } \\
\text { Timur }\end{array}$ & $11,245.9$ & $617,581.7$ & $\begin{array}{l}282,365 . \\
3\end{array}$ & $\begin{array}{l}122,392 . \\
1\end{array}$ & $52,044.1$ & $1,114.8$ & $\begin{array}{l}1,086,744 . \\
O\end{array}$ \\
\hline
\end{tabular}




\begin{tabular}{|c|c|c|c|c|c|c|c|c|}
\hline No & $\begin{array}{c}\text { Province } \\
\text { Name }\end{array}$ & PAUD & SD & SMP & SMA & SMK & SLB & TOTAL \\
\hline 20 & $\begin{array}{l}\text { Kalimanta } \\
\text { n Barat }\end{array}$ & $111,767.3$ & $557,467.8$ & $\begin{array}{l}216,699 . \\
2\end{array}$ & $\begin{array}{l}106,569 . \\
5\end{array}$ & $446,382.2$ & 831.4 & $9939,717.5$ \\
\hline 21 & $\begin{array}{l}\text { Kalimanta } \\
\text { n Tengah }\end{array}$ & $15,662.9$ & $266,313.1$ & $\begin{array}{l}116,317 . \\
8\end{array}$ & $45,006.0$ & $15,460.9$ & $1,093.2$ & $459,853.9$ \\
\hline 22 & $\begin{array}{l}\text { Kalimanta } \\
\text { n Selatan }\end{array}$ & $29,661.8$ & $264,564.1$ & $52,743.6$ & $36,147.2$ & $24,521.0$ & - & $407,637.7$ \\
\hline 23 & $\begin{array}{l}\text { Kalimanta } \\
\text { n Timur }\end{array}$ & $29,210.6$ & $177,631.6$ & $73,430.6$ & $45,521.7$ & $47,025.7$ & 761.2 & $373,581.4$ \\
\hline 24 & $\begin{array}{l}\text { Kalimanta } \\
\text { n Utara }\end{array}$ & $3,707.5$ & $54,809.1$ & $26,821.5$ & $13,098.7$ & - & - & $98,436.8$ \\
\hline 25 & $\begin{array}{l}\text { Sulawesi } \\
\text { Utara }\end{array}$ & 497.8 & $235,940.5$ & $81,035.3$ & $43,889.9$ & $34,101.3$ & $2,558.6$ & $398,023.5$ \\
\hline 26 & $\begin{array}{l}\text { Sulawesi } \\
\text { Tengah }\end{array}$ & $18,340.7$ & $294,867.3$ & $\begin{array}{l}108,115 . \\
5\end{array}$ & $38,306.3$ & $25,628.7$ & 995.0 & $486,253.6$ \\
\hline 27 & $\begin{array}{l}\text { Sulawesi } \\
\text { Selatan }\end{array}$ & $47,248.5$ & $619,988.8$ & $\begin{array}{l}176,019 . \\
2\end{array}$ & $\begin{array}{l}114,553 . \\
3\end{array}$ & $\begin{array}{l}100,077 . \\
5\end{array}$ & $3,769.3$ & $\begin{array}{l}1,061,656 . \\
5\end{array}$ \\
\hline 28 & $\begin{array}{l}\text { Sulawesi } \\
\text { Tenggara }\end{array}$ & $31,862.7$ & $255,722.4$ & $86,973.0$ & $65,143.6$ & $24,461.4$ & $6,012.7$ & $470,175.8$ \\
\hline 29 & Gorontalo & $6,652.3$ & $79,545.1$ & $36,217.0$ & $7,429.8$ & $9,928.1$ & - & $139,772.4$ \\
\hline 30 & $\begin{array}{l}\text { Sulawesi } \\
\text { Barat }\end{array}$ & $9,804.6$ & $161,077.8$ & $54,548.3$ & $10,101.0$ & $18,569.2$ & 598.6 & $254,699.6$ \\
\hline 31 & Maluku & $9,886.2$ & $224,426.0$ & $\begin{array}{l}123,342 . \\
\text { o }\end{array}$ & $76,478.9$ & $21,900.1$ & $1,556.3$ & $457,589.3$ \\
\hline 32 & $\begin{array}{l}\text { Maluku } \\
\text { Utara }\end{array}$ & $19,491.0$ & $179,545.9$ & $94,312.3$ & $58,535.1$ & $32,411.6$ & $1,182.1$ & $385,478.0$ \\
\hline 33 & $\begin{array}{l}\text { Papua } \\
\text { Barat }\end{array}$ & $4,541.0$ & $152,471.5$ & $42,141.2$ & $32,381.7$ & 6,530.0 & $4,414.9$ & $242,480.3$ \\
\hline 34 & Papua & $27,746.0$ & $636,076.1$ & $\begin{array}{l}222,209 . \\
3\end{array}$ & $\begin{array}{l}132,324 . \\
6\end{array}$ & $46,270.1$ & $19,265.1$ & $\begin{array}{l}1,083,891 . \\
1\end{array}$ \\
\hline & Total & $\begin{array}{l}1,545,32 \\
7\end{array}$ & $\begin{array}{l}14,709,03 \\
0\end{array}$ & $\begin{array}{l}4,627,82 \\
0\end{array}$ & $\begin{array}{l}2,809,54 \\
3\end{array}$ & $\begin{array}{l}\text { 3,435,68 } \\
1\end{array}$ & 121,052 & $\begin{array}{l}27,248,45 \\
6\end{array}$ \\
\hline & $\begin{array}{l}\text { West } \\
\text { Indonesia }\end{array}$ & $\begin{array}{l}1,175,54 \\
9\end{array}$ & $9,600,454$ & $\begin{array}{l}2,699,05 \\
8\end{array}$ & $\begin{array}{l}1,788,02 \\
4\end{array}$ & $\begin{array}{l}2,851,38 \\
5\end{array}$ & 73,745 & $\begin{array}{l}18,188,21 \\
7\end{array}$ \\
\hline & $\begin{array}{l}\text { East } \\
\text { Indonesia }\end{array}$ & 369,778 & $5,108,575$ & $\begin{array}{l}1,928,76 \\
1\end{array}$ & $\begin{array}{l}1,021,51 \\
9\end{array}$ & 584,296 & 47,307 & $9,060,238$ \\
\hline
\end{tabular}

\section{Scenario in Allocation of DAK Fisik in Education}

We exercise the allocation of DAK Fisik in the quadrant-based scenario. Each district or city is plotted in each quadrant which refers to particular treatment, possible incentives and disincentives which could be gained. There are two scenarios being exercised here. Both scenarios consider the fiscal capacity of each local government and the performance of local government to ensure the equity of allocation of DAK Fisik in the education sector. 
The first scenario as is illustrated in Figure 1 below, represents, index of education (X-axis) and index of fiscal capacity (Y-axis) The calculation of the Education Index follows the formula from the Directorate of Education - BAPPENAS as is shown below.

$$
\text { Education } \operatorname{Index}_{(j k)}=\frac{\sum_{i=1}^{n} N e w_{i j k}}{n}+\frac{\sum_{i=1}^{n} \operatorname{Reh}_{i j k}}{n}+\operatorname{Part}_{j k}+\operatorname{Comm}_{j k}
$$

It can be seen that the Education Index on j-level and k-municipal, equals to the sum of the average ratio to the needs of new infrastructures compared towards the existing

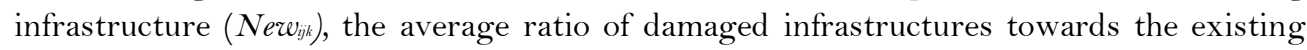
infrastructure $\left(R e h_{i k}\right)$, school participation index on j-level (Part $\left.t_{\mathrm{k}}\right)$, as well as the commitment index $\left(c o m m_{\mathrm{jk}}\right)$. This commitment index is the combination of indices which shows the quality of education, national exam scores, and implementation of DAK Fisik in education in the previous year. Furthermore, the data of fiscal capacity index is gained from the Ministry of Finance. The 2020 fiscal capacity data is utilized.

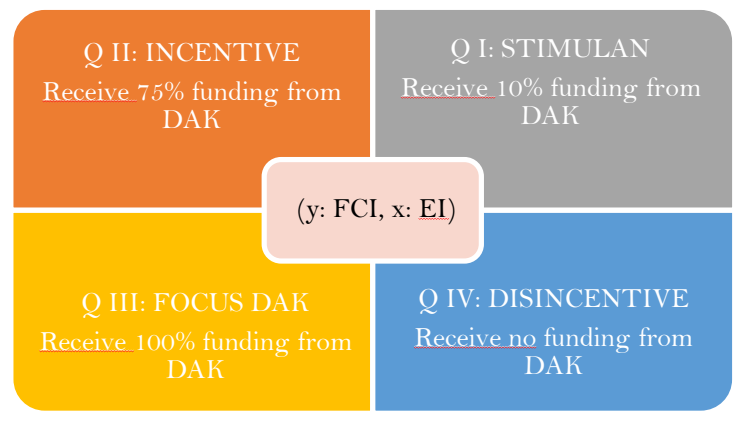

Figure 1. First Scenario

We estimate that allocation of DAK Fisik in education using the first scenario is smaller in amount than the allocation in the baseline scenario. The DAK Fisik in education for FY202 1 using this first scenario is only about 17,65 trillion rupiah. It is also estimated from this total amount that an allocation to the western part of Indonesia will be approximately 7,45 trillion rupiah (42.2\%) while the allocation for the eastern part of Indonesia will be around 10,2 trillion rupiah (57.7\%). Table 3 shows the detail of allocation per province using this first scenario.

Table 3. DAK Fisik in Education FY202 1 by education level per province (Scenario 1) (In Million Rupiah)

\begin{tabular}{|c|c|c|c|c|c|c|c|c|}
\hline No & Province Name & PAUD & SD & SMP & SMA & SMK & SLB & TOTAL \\
\hline 1 & Aceh & $7,7,840.9$ & $270,424.6$ & $34,594.7$ & $\begin{array}{l}11,874 . \\
8\end{array}$ & - & 4997.7 & $325,232.7$ \\
\hline 2 & Sumatera Utara & $22,911.8$ & $283,301.6$ & $\begin{array}{l}161,270 . \\
3\end{array}$ & $\begin{array}{l}87,052 . \\
4\end{array}$ & $\begin{array}{l}86,790 . \\
4\end{array}$ & $\begin{array}{l}1,459 . \\
7\end{array}$ & $642,786.4$ \\
\hline 3 & Sumatera Barat & $3,680.2$ & $312,634.5$ & $33,534.3$ & $\begin{array}{l}20,609 . \\
8\end{array}$ & $4,342.4$ & $\begin{array}{l}1,277 . \\
7\end{array}$ & $376,078.9$ \\
\hline 4 & Riau & $6,479.0$ & $321,974.6$ & $70,501.8$ & $\begin{array}{l}24,297 . \\
\text { o }\end{array}$ & $9,143.2$ & 28.5 & $432,424.2$ \\
\hline
\end{tabular}


Tengku Munawar Chalil and Mohammad Roudo

\begin{tabular}{|c|c|c|c|c|c|c|c|c|}
\hline 5 & Jambi & $4,545.0$ & $346,552.2$ & $30,105.9$ & $\begin{array}{l}10,824 . \\
2\end{array}$ & - & - & $392,027.2$ \\
\hline 6 & Sumatera Selatan & $6,631.5$ & $362,858.8$ & $34,954.7$ & $\begin{array}{l}12,226 . \\
6\end{array}$ & - & 282.4 & $416,954.0$ \\
\hline 7 & Bengkulu & 147.7 & $360,942.9$ & $1,345.0$ & - & - & - & $362,435.6$ \\
\hline 8 & Lampung & $7,055.7$ & $373,747.2$ & $19,097.9$ & - & - & 495.3 & $400,396.0$ \\
\hline 9 & $\begin{array}{l}\text { Kepulauan Bangka } \\
\text { Belitung }\end{array}$ & - & $393,052.9$ & - & - & - & - & $393,052.9$ \\
\hline 10 & Kepulauan Riau & $1,886.0$ & $376,694.2$ & $23,285.4$ & $8,991.1$ & - & 500.7 & $411,357.4$ \\
\hline 11 & DKI Jakarta & - & $384,723.6$ & - & - & - & - & $384,723.6$ \\
\hline 12 & Jawa Barat & $24,200.8$ & $387,084.7$ & $63,665.7$ & - & $\begin{array}{l}37,663 . \\
9\end{array}$ & 129.6 & $512,744.8$ \\
\hline 13 & Jawa Tengah & $17,648.4$ & $388,189.9$ & $13,456.3$ & $7,087.1$ & $1,528.1$ & 270.9 & $428,180.8$ \\
\hline 14 & DI Yogyakarta & $1,637.6$ & $380,565.8$ & $1,022.5$ & - & - & - & $383,225.9$ \\
\hline 15 & Jawa Timur & $39,184.1$ & $434,159.9$ & $71,424.2$ & $\begin{array}{l}21,188 . \\
3\end{array}$ & $\begin{array}{l}47,287 . \\
2\end{array}$ & 928.6 & $614,172.3$ \\
\hline 16 & Banten & $8,642.0$ & $432,883.0$ & $34,922.4$ & $\begin{array}{l}16,434 . \\
2\end{array}$ & $\begin{array}{l}15,275 . \\
6\end{array}$ & 440.0 & $508,597.2$ \\
\hline 17 & Bali & $7,094.8$ & $430,276.8$ & $11,960.3$ & $\begin{array}{l}11,149 . \\
5\end{array}$ & $9,868.8$ & - & $470,350.2$ \\
\hline 18 & $\begin{array}{l}\text { Nusa Tenggara } \\
\text { Barat }\end{array}$ & $14,941.5$ & $434,600.6$ & $29,764.5$ & $6,755.5$ & $1,406.7$ & - & $487,468.9$ \\
\hline 19 & $\begin{array}{l}\text { Nusa Tenggara } \\
\text { Timur }\end{array}$ & $8,330.1$ & $484,488.3$ & $\begin{array}{l}200,435 . \\
9\end{array}$ & $\begin{array}{l}77,172 . \\
8\end{array}$ & $\begin{array}{l}25,672 . \\
6\end{array}$ & 410.4 & $796,510.1$ \\
\hline 20 & Kalimantan Barat & $4,007.8$ & $498,080.6$ & $\begin{array}{l}118,753 . \\
1\end{array}$ & $\begin{array}{l}45,254 . \\
\text { o }\end{array}$ & $4,817.7$ & 218.6 & $671,131.8$ \\
\hline 21 & $\begin{array}{l}\text { Kalimantan } \\
\text { Tengah }\end{array}$ & $7,173.4$ & $520,084.2$ & $85,915.9$ & $\begin{array}{l}25,115 . \\
5\end{array}$ & - & 831.3 & $639,120.3$ \\
\hline 22 & $\begin{array}{l}\text { Kalimantan } \\
\text { Selatan }\end{array}$ & $12,186.3$ & $541,038.4$ & $26,505.9$ & $\begin{array}{l}11,500 . \\
9\end{array}$ & $5,767.0$ & - & $596,998.5$ \\
\hline 23 & Kalimantan Timur & $12,973.8$ & $552,884.9$ & $21,426.9$ & $4,178.4$ & - & - & $591,464.0$ \\
\hline 24 & Kalimantan Utara & 476.6 & $569,061.3$ & $17,573.3$ & $6,000.9$ & - & - & $593,112.1$ \\
\hline 25 & Sulawesi Utara & - & $562,675.9$ & $52,943.4$ & $\begin{array}{l}17,338 . \\
8\end{array}$ & $7,073.8$ & $\begin{array}{l}1,283 . \\
0\end{array}$ & $641,315.0$ \\
\hline 26 & Sulawesi Tengah & $15,120.0$ & $533,884.9$ & $88,961.6$ & $\begin{array}{l}27,270 . \\
4\end{array}$ & $\begin{array}{l}15,776 . \\
3\end{array}$ & 809.3 & $681,822.6$ \\
\hline 27 & Sulawesi Selatan & $17,193.1$ & $512,682.9$ & $57,398.8$ & $\begin{array}{l}23,909 . \\
4\end{array}$ & $\begin{array}{l}21,595 . \\
6\end{array}$ & 996.2 & $633,776.0$ \\
\hline 28 & $\begin{array}{l}\text { Sulawesi } \\
\text { Tenggara }\end{array}$ & $15,229.5$ & $481,955.8$ & $41,520.2$ & $\begin{array}{l}23,214 . \\
8\end{array}$ & 1,239.6 & $\begin{array}{l}2,871 \\
6\end{array}$ & $566,031.4$ \\
\hline 29 & Gorontalo & 2,237.0 & $449,629.3$ & $26,876.7$ & $2,025.7$ & $3,718.0$ & - & $484,486.6$ \\
\hline 30 & Sulawesi Barat & $4,376.7$ & $439,624.3$ & $39,369.2$ & $3,969.3$ & $8,458.9$ & 330.1 & $496,128.5$ \\
\hline
\end{tabular}


Tengku Munawar Chalil and Mohammad Roudo

\begin{tabular}{|c|c|c|c|c|c|c|c|c|}
\hline 31 & Maluku & $7,606.8$ & $417,125.4$ & $\begin{array}{l}101,153 . \\
2\end{array}$ & $\begin{array}{l}56,923 . \\
3\end{array}$ & $\begin{array}{l}12,148 . \\
5\end{array}$ & 924.0 & $595,881.2$ \\
\hline 32 & Maluku Utara & $13,896.6$ & $393,589.8$ & $65,594.8$ & $\begin{array}{l}40,507 . \\
5\end{array}$ & $\begin{array}{l}12,238 . \\
5\end{array}$ & 603.3 & $526,430.5$ \\
\hline 33 & Papua Barat & $3,809.2$ & $398,056.5$ & $37,871.6$ & $\begin{array}{l}25,604 . \\
3\end{array}$ & $2,537.3$ & $\begin{array}{l}4,211 . \\
5\end{array}$ & $472,090.5$ \\
\hline 34 & Papua & $17,751.9$ & $380,297.0$ & $\begin{array}{l}179,742 . \\
2\end{array}$ & $\begin{array}{l}96,539 . \\
1\end{array}$ & $\begin{array}{l}28,287 \\
8\end{array}$ & $\begin{array}{l}16,02 \\
4.7\end{array}$ & $718,642.6$ \\
\hline & Total & $\begin{array}{l}316,895 \\
7\end{array}$ & $\begin{array}{l}14,409,82 \\
7.4\end{array}$ & $\begin{array}{l}1,796,94 \\
8.7\end{array}$ & $\begin{array}{l}725,01 \\
5.8\end{array}$ & $\begin{array}{l}362,63 \\
8.1\end{array}$ & $\begin{array}{l}35,82 \\
5.0\end{array}$ & $\begin{array}{l}17,647,15 \\
0.6\end{array}$ \\
\hline & West Indonesia & $\begin{array}{l}159,585 . \\
4\end{array}$ & $\begin{array}{l}6,240,067 \\
.1\end{array}$ & $\begin{array}{l}605,141 . \\
5\end{array}$ & $\begin{array}{l}231,73 \\
5.0\end{array}$ & $\begin{array}{l}211,89 \\
9.7\end{array}$ & $\begin{array}{l}6,311 . \\
2\end{array}$ & $\begin{array}{l}7,454,740 \\
.0\end{array}$ \\
\hline & East Indonesia & $\begin{array}{l}157,310 . \\
3\end{array}$ & $\begin{array}{l}8,169,760 \\
.3\end{array}$ & $\begin{array}{l}1,191,80 \\
7.2\end{array}$ & $\begin{array}{l}493,28 \\
0.7\end{array}$ & $\begin{array}{l}150,73 \\
8.4\end{array}$ & $\begin{array}{l}29,51 \\
3.8\end{array}$ & $\begin{array}{l}10,192,41 \\
0.6\end{array}$ \\
\hline
\end{tabular}

The second scenario as is shown in Figure 2, uses the Education PrAda Index instead of the Education Index on the X-axis. However, it still used the Fiscal Capacity Index on the Y-axis. The PrAda Index shows the performance of local government in several sectors using the specific village data (PoDes). This data is initiated by the Directorate of Regional Development- BAPPENAS.

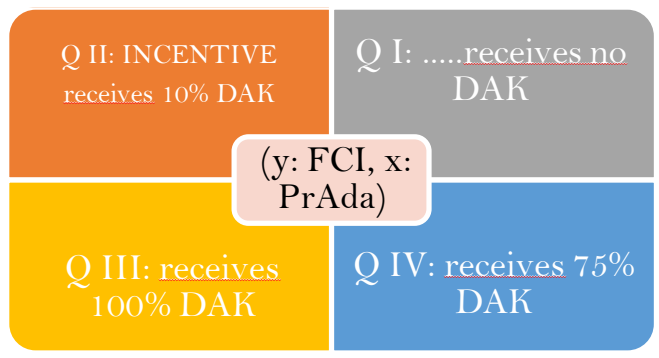

Figure 2. Second Scenario

We calculated and estimated the amount of DAK Fisik in education for FY2021 with the second scenario totalling about 19,26 trillion rupiah. By this total amount, the western part of Indonesia will receive 8,27 trillion rupiah (43\%) while the eastern part of Indonesia will receive 11 trillion rupiah $(57 \%)$. Table 4 shows the detail of allocation per province by using this second scenario.

Table 4. DAK Fisik in Education FY2021 by education level per province (Scenario 2) (In Million Rupiah)

\begin{tabular}{lllllllll}
\hline No & Province Name & PAUD & SD & SMP & SMA & SMK & SLB & TOTAL \\
\hline \hline 1 & Aceh & $21,833.8$ & $270,424.6$ & $117,174$. & $75,199.9$ & $23,050$. & $2,127.3$ & $509,810.7$ \\
& & & & 9 & 8 & 08 & 1 & 5 \\
2 & \multirow{2}{*}{ Sumatera Utara } & $30,212.7$ & $283,301.6$ & $197,879$. & $115,898$. & 112,212 & $2,954.5$ & $742,458.8$ \\
& & & & 22 & 23 & .53 & 6 & 4
\end{tabular}


Tengku Munawar Chalil and Mohammad Roudo

\begin{tabular}{|c|c|c|c|c|c|c|c|c|}
\hline No & Province Name & PAUD & SD & SMP & SMA & SMK & SLB & TOTAL \\
\hline \multirow[t]{2}{*}{3} & Sumatera Barat & $6,273.7$ & $312,634.4$ & $477,217.1$ & $33,879.0$ & $15,222$. & $3,463.4$ & $4418,690.4$ \\
\hline & & & & 7 & 9 & 54 & 7 & 7 \\
\hline \multirow[t]{2}{*}{4} & Riau & $2,287.5$ & $321,974.6$ & $13,474.7$ & - & - & - & $337,200.5$ \\
\hline & & & & 5 & & & & 3 \\
\hline \multirow[t]{2}{*}{5} & Jambi & $4,489.0$ & $346,552.1$ & $50,082.6$ & $22,656.3$ & $9,869.9$ & - & $433,650.1$ \\
\hline & & & & 2 & 5 & 6 & & 1 \\
\hline \multirow[t]{2}{*}{6} & Sumatera & 6,226 & $362,858.7$ & $42,457.1$ & $20,970.6$ & - & 506.98 & $433,020.1$ \\
\hline & Selatan & & & o & 3 & & & o \\
\hline \multirow[t]{2}{*}{7} & Bengkulu & $1,378.9$ & $360,942.8$ & $33,856.0$ & $14,753.4$ & 11,546 & 72.89 & $422,551.0$ \\
\hline & & & & 4 & 9 & 78 & & 3 \\
\hline \multirow[t]{2}{*}{8} & Lampung & $25,707.3$ & $373,747.1$ & $77,721.8$ & $36,221.9$ & 36,019 & 780.27 & $550,197.5$ \\
\hline & & & & 4 & & 01 & & 3 \\
\hline \multirow[t]{2}{*}{9} & Kepulauan & 11,515 & $393,052.9$ & $13,967.5$ & $7,405.13$ & $6,726.1$ & - & $432,667.4$ \\
\hline & Bangka Belitung & & & 6 & & 6 & & 6 \\
\hline \multirow[t]{2}{*}{10} & Kepulauan Riau & $1,709.4$ & $376,694.2$ & $22,597.6$ & $11,189.1$ & $4,588.5$ & 746.39 & $417,525.4$ \\
\hline & & & & 1 & 5 & 9 & & o \\
\hline \multirow[t]{2}{*}{11} & DKI Jakarta & 41,891 & $384,723.6$ & $27,468.1$ & $65,478.9$ & 130,760 & $2,602.7$ & $652,924.7$ \\
\hline & & & & 6 & 1 & .2 & 1 & o \\
\hline \multirow[t]{2}{*}{12} & Jawa Barat & $2,512.8$ & $387,084.6$ & $15,096.4$ & - & - & - & $404,694.0$ \\
\hline & & & & 6 & & & & 2 \\
\hline \multirow[t]{2}{*}{13} & Jawa Tengah & 36,445 & $388,189.9$ & $26,469.5$ & $16,969.6$ & 40,521 & 1,270.0 & $509,866.2$ \\
\hline & & & & 6 & 7 & 9 & 1 & 2 \\
\hline \multirow[t]{2}{*}{14} & DI Yogyakarta & - & $380,565.7$ & - & - & - & - & $380,565.7$ \\
\hline & & & & & & & & 9 \\
\hline \multirow[t]{2}{*}{15} & Jawa Timur & $26,004.1$ & $434,159.9$ & 121,347 & $34,036.5$ & 73,542 . & 797.90 & $689,888.1$ \\
\hline & & & & 40 & 1 & 3 & & 8 \\
\hline \multirow[t]{2}{*}{16} & Banten & $4,645.4$ & 432,883 & $22,069.0$ & $12,015.7$ & 18,128 & 612.01 & $490,353.5$ \\
\hline & & & & 7 & 3 & 3 & & 7 \\
\hline \multirow[t]{2}{*}{17} & Bali & $1,808.4$ & $430,276.7$ & $4,120.77$ & $3,604.85$ & $1,303.2$ & - & $441,114.1$ \\
\hline & & & & & & & & 1 \\
\hline \multirow[t]{2}{*}{18} & Nusa Tenggara & 38,117 & $434,600.6$ & $60,726.9$ & $32,548.3$ & 25,703 & $2,136.6$ & $593,832.9$ \\
\hline & Barat & & & o & 6 & 45 & 2 & 3 \\
\hline \multirow[t]{2}{*}{19} & Nusa Tenggara & $10,579.7$ & $484,488.2$ & 274,457 & 116,433 & 47,922 . & 994.95 & $934,875.7$ \\
\hline & Timur & & & 20 & 27 & 33 & & 5 \\
\hline \multirow[t]{2}{*}{20} & Kalimantan & $4,533.8$ & $498,080.6$ & 180,239 & $82,946.5$ & 29,127 . & 430.88 & $795,359.2$ \\
\hline & Barat & & & 55 & 4 & 81 & & 2 \\
\hline \multirow[t]{2}{*}{21} & Kalimantan & $12,031.7$ & $520,084.1$ & $86,787.4$ & $34,997.0$ & $5,280.4$ & 522.11 & $659,703.0$ \\
\hline & Tengah & & & 2 & 9 & 5 & & 3 \\
\hline \multirow[t]{2}{*}{22} & Kalimantan & $9,886.2$ & $541,038.4$ & $22,100.2$ & $12,434.5$ & $4,756.5$ & - & $590,215.9$ \\
\hline & Selatan & & & 1 & 4 & 1 & & 8 \\
\hline 23 & $\begin{array}{l}\text { Kalimantan } \\
\text { Timur }\end{array}$ & $1,877.5$ & $552,884.8$ & $6,091.71$ & - & - & - & $\begin{array}{l}560,854.1 \\
4\end{array}$ \\
\hline
\end{tabular}




\begin{tabular}{|c|c|c|c|c|c|c|c|c|}
\hline No & Province Name & PAUD & SD & SMP & SMA & SMK & SLB & TOTAL \\
\hline 24 & $\begin{array}{l}\text { Kalimantan } \\
\text { Utara }\end{array}$ & 2,997 & $569,061.3$ & $\begin{array}{l}23,937.8 \\
7\end{array}$ & $\begin{array}{l}12,337.6 \\
9\end{array}$ & - & - & $\begin{array}{l}608,333.9 \\
9\end{array}$ \\
\hline 25 & Sulawesi Utara & 373.3 & $562,675.8$ & $\begin{array}{l}61,794.1 \\
5\end{array}$ & $\begin{array}{l}24,611.5 \\
2\end{array}$ & $\begin{array}{l}13,916 . \\
26\end{array}$ & $\begin{array}{l}1,698.9 \\
8\end{array}$ & $\begin{array}{l}665,070.1 \\
5\end{array}$ \\
\hline 26 & $\begin{array}{l}\text { Sulawesi } \\
\text { Tengah }\end{array}$ & $13,563.8$ & $533,884.9$ & $\begin{array}{l}79,085.8 \\
4\end{array}$ & $\begin{array}{l}24,111.9 \\
1\end{array}$ & $\begin{array}{l}14,991 . \\
33\end{array}$ & 646.00 & $\begin{array}{l}666,283.8 \\
4\end{array}$ \\
\hline 27 & Sulawesi Selatan & $26,904.7$ & $512,682.8$ & $\begin{array}{l}129,431 . \\
20\end{array}$ & $\begin{array}{l}66,614.0 \\
8\end{array}$ & $\begin{array}{l}62,837 . \\
55\end{array}$ & $\begin{array}{l}1,826.8 \\
4\end{array}$ & $\begin{array}{l}800,297.2 \\
7\end{array}$ \\
\hline 28 & $\begin{array}{l}\text { Sulawesi } \\
\text { Tenggara }\end{array}$ & $19,883.1$ & $481,955.8$ & $\begin{array}{l}61,910.9 \\
0\end{array}$ & $\begin{array}{l}41,571.4 \\
2\end{array}$ & $\begin{array}{l}12,637 . \\
07\end{array}$ & $\begin{array}{l}4,893.3 \\
7\end{array}$ & $\begin{array}{l}622,851.7 \\
8\end{array}$ \\
\hline 29 & Gorontalo & $4,989.2$ & $449,629.2$ & $\begin{array}{l}27,162.7 \\
6\end{array}$ & $4,934.87$ & $\begin{array}{l}6,887.6 \\
6\end{array}$ & - & $\begin{array}{l}493,603.8 \\
0\end{array}$ \\
\hline 30 & Sulawesi Barat & $7,515.6$ & $439,624.3$ & $\begin{array}{l}49,013.3 \\
2\end{array}$ & $9,299.27$ & $\begin{array}{l}15,778 . \\
25\end{array}$ & 406.14 & $\begin{array}{l}521,636.9 \\
3\end{array}$ \\
\hline 31 & Maluku & 9,683 & $417,125.4$ & $\begin{array}{l}122,031 . \\
63\end{array}$ & $74,528.1$ & $\begin{array}{l}20,444 . \\
78\end{array}$ & $\begin{array}{l}1,534.0 \\
9\end{array}$ & $\begin{array}{l}645,347.0 \\
7\end{array}$ \\
\hline 32 & Maluku Utara & $18,573.9$ & $393,589.8$ & $\begin{array}{l}91,329.6 \\
8\end{array}$ & $53,801.3$ & $\begin{array}{l}31,170 . \\
35\end{array}$ & $\begin{array}{l}1,010.2 \\
7\end{array}$ & $\begin{array}{l}589,475.4 \\
3\end{array}$ \\
\hline 33 & Papua Barat & $4,254.7$ & $398,056.5$ & $\begin{array}{l}37,460.6 \\
4\end{array}$ & 25,156 & $\begin{array}{l}5,134.9 \\
0\end{array}$ & $\begin{array}{l}3,943.9 \\
2\end{array}$ & $\begin{array}{l}474,006.7 \\
6\end{array}$ \\
\hline 34 & Papua & $18,124.4$ & 380,297 & $\begin{array}{l}203,733 . \\
91\end{array}$ & $\begin{array}{l}119,100 . \\
5\end{array}$ & $\begin{array}{l}31,226 . \\
32\end{array}$ & $\begin{array}{l}18,597 . \\
55\end{array}$ & $771,079.8$ \\
\hline & Total & $\begin{array}{l}428,831 . \\
3\end{array}$ & $\begin{array}{l}14,409,82 \\
7.3\end{array}$ & $\begin{array}{l}2,350,29 \\
5.1\end{array}$ & $\begin{array}{l}1,205,16 \\
9.8\end{array}$ & $\begin{array}{l}811,306 \\
.8\end{array}$ & $\begin{array}{l}54,576 . \\
2\end{array}$ & $\begin{array}{l}19,260,00 \\
6.7\end{array}$ \\
\hline & West Indonesia & $\begin{array}{l}224,941 . \\
9\end{array}$ & $\begin{array}{l}6,240,067 \\
.1\end{array}$ & $\begin{array}{l}833,000 . \\
2\end{array}$ & $\begin{array}{l}469,743 . \\
2\end{array}$ & $\begin{array}{l}483,491 \\
.7\end{array}$ & $\begin{array}{l}15,934 . \\
5\end{array}$ & $\begin{array}{l}8,267,178 \\
.8\end{array}$ \\
\hline & East Indonesia & $\begin{array}{l}203,889 . \\
3\end{array}$ & $\begin{array}{l}8,169,760 \\
.2\end{array}$ & $\begin{array}{l}1,517,29 \\
4.9\end{array}$ & $\begin{array}{l}735,426 . \\
5\end{array}$ & $\begin{array}{l}327,815 \\
.0\end{array}$ & $\begin{array}{l}38,641 . \\
7\end{array}$ & $\begin{array}{l}10,992,82 \\
7.9\end{array}$ \\
\hline
\end{tabular}

\section{Conclusion}

This paper offers the top-down approach in the calculation of DAK Fisik in the education sector. The calculation departs from previous methods by estimating the need of the infrastructures in education by seeking to fill the gap between the current and the ideal condition of the infrastructure. The gap is then calculated and estimated into the exercise of costing. After that, the estimated cost could be financed by DAK Fisik and is calculated and projected within a particular time frame and scenario.

Without ignoring the importance and the successful implementation of the current bottom-up approach, the idea of the top-down approach is also essential to factor into the process. This top-down approach through the formula presented is necessary as a baseline and guidance for policymakers to accurately predict the overall needs of DAK Fisik based on valid and reliable data and pertinent information being taken into account. Furthermore, this formula-based (top-down) approach is also useful to give the idea for the central government 
to help them ascertain whether the proposals from the local government are either underbudget or over-budget.

The idea of this top-down approach is not aimed to replace the bottom-up approach through the proposal based in KRISNA DAK. The bottom-up approach could still be endorsed since the central government may not have sufficient good judgment and may encourage active participation for local government to provide valid and reliable data and essential information through their proposals during the application process. We recommend the best alternative as being the combination of both the top-down and bottomup approaches.

However, we still consider some weaknesses in this formula-based approach. For instance, it could not adapt to any major negative factors during the development process. For example, this approach is not flexible for any disaster or emergency condition, i.e., the COVID-19 pandemic. This approach also relies too much on the supply and accuracy of data. In the case regarding the education sector, the data came from self-reporting from the school headmasters. School headmasters may report small damage in a classroom as "damaged," with fewer appraisals from officials in public works departments (Dinas Pekerjaan Umum).

Finally, there are some elements that should be fulfilled to ensure the successful implementation of the proposed approach. For instance, the ministry/agency should set a clear target in each planning document. In the case of the education sector, the Ministry of Education and Culture should mention a clear target about how many newly built or restoration of damaged infrastructures should be done over a particular time frame in each ministry/agency planning document. This target should be later translated into a "road map," which is then transformed to the needs of the budget available.

Acknowledgement: The authors wish to thank the Directorate of Regional Autonomy, the Directorate of Regional Development and the Directorate of Education and Religion, the Ministry of Development Planning (BAPPENAS), the Ministry of Education and Culture and the KOMPAK Project for assisting with data and information, facilitating the discussion and giving helpful inputs, comments and feedback.

\section{References}

Denzau, A. T. (1975). An empirical survey of studies on public school spending. National Tax Journal, 241-249.

Hirsch, W. Z. (1960). Determinants of public education expenditures. National Tax Journal, 13(1), 29-40.

Kurban, H., Gallagher, R. M., \& Persky, J. J. (2015). Demographic changes and education expenditures: A reinterpretation. Economics of Education Review, 45, 103-108.

Ladd, H. F. (1975). Local education expenditures, fiscal capacity, and the composition of the property tax base. National Tax Journal, 145-158.

Ma, J. (1999). Intergovernmental Fiscal Transfer: A Comparison of Nine Countries (Cases of the United States, Canada, the United Kingdom, Australia, Germany, Japan, Korea, India, and Indonesia). The World Bank. DOI: 10.1596/1813-9450-1822 
Mochida, N. (2007). Measuring Fiscal Needs: Japan's Experience. CIRJE Working Paper. Center for International Research on the Japanese Economy, Faculty of Economics, University of Tokyo.

Patrinos, H. A., \& Ariasingam, D. L. (1997). Decentralization of education: demand-side financing. The World Bank.

Porcelli, F., \& Vidoli, F. (2019). A comprehensive model for the evaluation of standard expenditure needs and standard level of local services. Local Government Studies, 1-29.

Rosnes, O., \& Vennemo, H. (2009). Powering up: costing power infrastructure spending needs in Sub-Saharan Africa. World Bank Working Paper. DOI: 10.1596/28073

Schick (1998). A Contemporary Approach to Public Expenditure Management. The World Bank Institute: 35116

Shah, A., Qibthiyyah, R., \& Dita, A. (2012). General purpose central-provincial-local transfers (dau) in Indonesia: From gap filling to ensuring fair access to essential public services for all. The World Bank. DOI: 10.1596/1813-9450-6075

Stiglitz, J. E. (1974). The demand for education in public and private school systems. Journal of Public Economics, 3(4), 349-385.

West, A., Pennell, H., Travers, T., \& West, R. (2001). Financing school-based education in England: poverty, examination results, and expenditure. Environment and Planning $C$ : Government and Policy, 19(3), 461-471. 